\title{
Can reduction mammoplasty patients be promised a particular size postoperatively?
}

\author{
Arianna Dal Cin BSC MD FRCSC, Elizabeth Rose Jeans BSC MD FRCPC
}

A Dal Cin, ER Jeans. Can reduction mammoplasty patients be promised a particular size postoperatively? Can J Plast Surg 2005;13(1):13-15.

This retrospective study used self-reported bra sizes, heights and weights pre- and postoperatively in patients who underwent reduction mammoplasty by one surgeon between 2001 and 2003. Preoperative data were collected on 91 patients. Postoperative data were collected from 69 respondents by telephone survey. Bra sizes were standardized according to cup size. In bra-making, the cup is the same size for decreasing cup letter size as the band size increases. The most common standardized cup size was seven, representing bra sizes $34 \mathrm{~F}, 36 \mathrm{E}, 38 \mathrm{D}, 40 \mathrm{C}$, etc. The range of preoperative cup sizes was five $(34 \mathrm{D})$ to $17(42 \mathrm{~L})$. The mass of tissue removed from each breast was averaged for each patient and ranged from $147 \mathrm{~g}$ to $2453 \mathrm{~g}$ (mean $522 \mathrm{~g}$ ). The average body mass index was $29.6 \mathrm{~kg} / \mathrm{m}^{2}$ preoperatively and $29.3 \mathrm{~kg} / \mathrm{m}^{2}$ postoperatively, with six patients reporting weight gain, 13 reporting weight loss and 50 reporting no change at all. Postoperative standardized cup sizes ranged from five (34 D) to 14 $(44 \mathrm{H})$. The difference between pre- and postoperative cup size ranged from zero to eight as follows: for no cup size change $(n=17)$, mean tissue removed per breast was $577.1 \mathrm{~g}$; decrease by one cup size $(n=23), 489.2 \mathrm{~g}$; decrease by two cup sizes $(n=25), 425.8 \mathrm{~g}$.

These data indicate that when self-reported data from patients are used, a plastic surgeon may find that as many as $25 \%$ report no change in bra size after reduction mammoplasty, even when more than $500 \mathrm{~g}$ of tissue is removed from each breast, which may adversely affect patients' satisfaction with the surgical results. Future studies will determine the cause of the apparent discrepancy between operative and self-reported results.

Key Words: Bra cup size; Reduction mammoplasty

\section{Peut-on promettre un tour de poitrine précis après l'opération aux patientes qui subissent une réduction mammaire?}

La présente étude rétrospective a fait appel au tour de poitrine, à la taille et au poids transmis par les patientes avant et après une opération de réduction mammaire effectuée par un chirurgien entre 2001 et 2003. Les données préopératoires ont été recueillies auprès de 91 patientes; les données postopératoires, auprès de 69 répondantes, par sondage téléphonique. La taille du soutien-gorge a été normalisée d'après la taille du bonnet. Dans la fabrication des soutiens-gorge, le bonnet est de la même taille pour des lettres décroissantes à mesure que le tour de thorax augmente. La taille de bonnet normalisée la plus courante était de sept, représentant les tailles de soutien-gorge 34 F, 36 E, 38 D, 40 C, etc. La plage de tailles de bonnet préopératoires oscillait entre cinq (34 D) et 17 (42 L). La masse de tissus retirée de chaque sein a été moyennée pour chaque patiente et variait entre $147 \mathrm{~g}$ et $2453 \mathrm{~g}$ (moyenne de $522 \mathrm{~g}$ ). L'indice de masse corporelle moyen était de $29,6 \mathrm{~kg} / \mathrm{m}^{2}$ avant l'opération et de $29,3 \mathrm{~kg} / \mathrm{m}^{2}$ après l'opération, six patientes ayant déclaré un gain de poids, 13 , une perte de poids et 50, aucun changement. Les tailles de bonnet normalisées après l'opération variaient entre cinq $(34 \mathrm{D})$ et 14 $(44 \mathrm{H})$. La différence entre la taille de bonnet préopératoire et postopératoire variait entre zéro et huit. Ainsi, lorsque le bonnet demeurait le même ( $\mathrm{n}=17)$, la quantité moyenne de tissus retirée était de $577,1 \mathrm{~g}$; lorsque le bonnet diminuait de un $(\mathrm{n}=23)$, l'exérèse moyenne était de $489,2 \mathrm{~g}$, et lorsqu'il diminuait de deux $(\mathrm{n}=25)$, de $425,8 \mathrm{~g}$.

Ces données indiquent que s'il se fonde sur les données transmises par les patientes, le plasticien peut découvrir que jusqu'à $25 \%$ d'entre elles ne déclarent aucune modification de la taille de leur soutien-gorge après une réduction mammaire, même si plus de $500 \mathrm{~g}$ de tissus sont retirés de chaque sein, ce qui peut entacher leur satisfaction face aux résultats de l'opération. De futures études permettront de déterminer la cause de l'écart apparent entre les résultats opératoires et les résultats signalés par les patientes.

Part of the difficulty lies with the lack of standardization of bra sizes, not only by being differently constructed by various manufacturers, but also by women's tendency to wear improperly fitting bras. At least two studies have demonstrated a 70\% to $100 \%$ discrepancy between the bra size the patient believes herself to be and her actual measured size $(2,3)$. This variability makes it difficult for us, as plastic surgeons, to apply a mathematical formula to produce a specific decrease in bra size to fulfill a patient's request.

In North America, bra size reflects the band size (numerical component) and the cup size (letter component). The band size is determined by measuring the chest wall circumference moplasty. The plastic surgeon is frequently asked what bra size the patient will be following surgery, and there is often a request by the patient for a particular cup size.

Today, there are no data correlating a particular cup size with a specific amount of breast tissue, although attempts have been made by various authors over the years to calculate this relationship. Techniques have included volume displacement (1), use of calipers and measurement of breast circumference (2), among others (3). No study has quantified a particular cup size with a specific tissue volume or mass.

Department of Surgery, Division of Plastic Surgery, McMaster University; Victoria Medical Centre, Hamilton, Ontario

Correspondence and reprints: Dr Arianna Dal Cin, Victoria Medical Centre, 504-304 Victoria Avenue North, Hamilton, Ontario L8L 5G4.

Telephone 905-526-0811, fax 905-526-0890, e-mail adc.mcedwards@skylinc.net 
TABLE 1

Standardized bra cup sizes

\begin{tabular}{ccccccccccccc}
\hline & A & B & C & D & E & F & G & H & I & J & K & L \\
\hline $\mathbf{3 2}$ & 1 & 2 & 3 & 4 & 5 & 6 & 7 & 8 & 9 & 10 & 11 & 12 \\
$\mathbf{3 4}$ & 2 & 3 & 4 & 5 & 6 & 7 & 8 & 9 & 10 & 11 & 12 & 13 \\
$\mathbf{3 6}$ & 3 & 4 & 5 & 6 & 7 & 8 & 9 & 10 & 11 & 12 & 13 & 14 \\
$\mathbf{3 8}$ & 4 & 5 & 6 & 7 & 8 & 9 & 10 & 11 & 12 & 13 & 14 & 15 \\
$\mathbf{4 0}$ & 5 & 6 & 7 & 8 & 9 & 10 & 11 & 12 & 13 & 14 & 15 & 16 \\
$\mathbf{4 2}$ & 6 & 7 & 8 & 9 & 10 & 11 & 12 & 13 & 14 & 15 & 16 & 17 \\
$\mathbf{4 4}$ & 7 & 8 & 9 & 10 & 11 & 12 & 13 & 14 & 15 & 16 & 17 & - \\
$\mathbf{4 6}$ & 8 & 9 & 10 & 11 & 12 & 13 & 14 & 15 & 16 & 17 & - & - \\
$\mathbf{4 8}$ & 9 & 10 & 11 & 12 & 13 & 14 & 15 & 16 & 17 & - & - & -
\end{tabular}

directly under the breasts and adding four or five inches to achieve an even number. The cup size is determined by measuring the circumference of the chest at the level of the fullest part of the breasts and subtracting the band size. A one inch difference between band size and breast measurement indicates an 'A' cup, two inches a 'B' cup, three inches a ' $\mathrm{C}$ ' cup and so on. Thus, a patient who measures 29 or 30 inches below the bust and 38 inches around the bust would wear a $34 \mathrm{D}$ bra.

The present study was undertaken to determine the relationship between a change in bra size and the amount of tissue removed in patients who have recently undergone reduction mammoplasty surgery. The ultimate goal was to develop a surgical guide relating tissue removal to desired bra size.

\section{METHODS}

A retrospective review was conducted of a single surgeon's (ADC) postreduction mammoplasty patients between 2001 and 2003. Pre- and postoperative self-reported bra sizes, heights and weights were collected on 91 patients. Postoperative data were collected by telephone survey or follow-up visits from 69 respondents (75.8\%), with follow-up visits ranging from six months to two years after surgery.

In bra manufacturing, the same breast volume would be labelled with a smaller cup size because the band size is increased (4). For instance, the cup pattern and underwire used to create a $34 \mathrm{D}$ cup is the same as that for a $36 \mathrm{C}$ and a $38 \mathrm{~B}$; only the pattern for the band is changed. This information allowed bra sizes to be standardized (Table 1) and facilitated comparisons among breast volumes. Thus, a patient reporting a preoperative bra size of $40 \mathrm{D}$ would be considered to have no cup size change if she wore a $38 \mathrm{E}$ postoperatively; if she wore a $40 \mathrm{C}$ or $38 \mathrm{D}$, she was considered to have a decrease of one cup size; and if she wore a $40 \mathrm{~B}$ or $38 \mathrm{C}$, she was considered to have a decrease of two cup sizes.

\section{Surgical technique}

All breasts were resected using the inferior pedicle technique. Tumescent infiltration was not used, although local anesthetic was injected into each breast immediately before resection. A total of $25 \mathrm{~mL}$ of $0.5 \%$ xylocaine with adrenaline was infiltrated into each breast. Thus, the local anesthetic did not significantly contribute to the mass of the resected tissue.

\section{RESULTS}

The 91 patients surveyed ranged from 19 to 72 years of age, with a mean of 42.1 years of age. The mean body mass index (BMI) was $29.6 \mathrm{~kg} / \mathrm{m}^{2}$. Twelve patients (13\%) had a BMI less than $25 \mathrm{~kg} / \mathrm{m}^{2} ; 39(43 \%)$ had a BMI of $25 \mathrm{~kg} / \mathrm{m}^{2}$ to $29.9 \mathrm{~kg} / \mathrm{m}^{2}$; and $40(44 \%)$ had a BMI of $30 \mathrm{~kg} / \mathrm{m}^{2}$ or greater.
TABLE 2

Self-reported pre- and postoperative measurements and mean tissue removed per breast according to the selfreported change in standardized bra cup size

\begin{tabular}{|c|c|c|c|c|c|c|}
\hline & \multicolumn{6}{|c|}{ Change in standardized bra cup size } \\
\hline & 0 & 1 & 2 & 3 & 4 & 8 \\
\hline Patients (n) & 17 & 23 & 25 & 1 & 2 & 1 \\
\hline $\begin{array}{l}\text { Mean preoperative body } \\
\text { mass index }\left(\mathrm{kg} / \mathrm{m}^{2}\right)\end{array}$ & 30.3 & 29.4 & 28.8 & 31.6 & 33.1 & 36.5 \\
\hline $\begin{array}{l}\text { Mean postoperative body } \\
\text { mass index }\left(\mathrm{kg} / \mathrm{m}^{2}\right)\end{array}$ & 30.5 & 29.4 & 28.5 & 31.6 & 29.1 & 36.5 \\
\hline $\begin{array}{l}\text { Mean preoperative } \\
\text { standardized bra cup size }\end{array}$ & 8.8 & 7.8 & 8.2 & 8 & 9 & 17 \\
\hline $\begin{array}{l}\text { Mean postoperative } \\
\text { standardized bra cup size }\end{array}$ & 8.8 & 6.8 & 6.2 & 5 & 5 & 9 \\
\hline Mean tissue removed $(\mathrm{g})$ & 577.1 & 489.2 & 425.8 & 658 & 516 & 2452 \\
\hline
\end{tabular}

The modal, preoperative standardized bra cup size was seven, representing sizes 34 F, $36 \mathrm{E}, 38 \mathrm{D}$ and so on. The mean standardized bra cup size preoperatively was 8.4. The range of sizes was five ( $34 \mathrm{D})$ to 17 (42 L). For each patient, the mass of tissue removed was averaged between the left and right breasts, and ranged from $147 \mathrm{~g}$ to $2453 \mathrm{~g}$, with a mean of $522 \mathrm{~g}$. The change in bra cup size after surgery ranged from zero to eight cup sizes.

Seventeen patients $(25 \%)$ reported no change in standardized bra cup size after surgery. The mean tissue removed per breast was $577 \mathrm{~g}$. The mean bra cup size pre- and postoperatively was 8.8 , with a range of $34 \mathrm{E}$ to $44 \mathrm{H}$, mode $38 \mathrm{E}$. The mean BMI among these patients was $30.3 \mathrm{~kg} / \mathrm{m}^{2}$.

Table 2, which groups respondents according to their reported change in bra size, summarizes the BMI, cup sizes and amount of tissue removed for each respective group. Overall, the differences between groups did not reach statistical significance but the trend toward more obesity with less cup change was observed in the three groups with more than two patients, that is the patients reporting zero, one or two changes in bra cup size.

Of note, all patients reported satisfaction with their postoperative size by six months after surgery, even though some had expressed concerns earlier that the size of their breasts had not been reduced enough. By six to 24 months follow-up, all patients reported feeling satisfied that their breasts were in proportion with their general body habitus.

\section{DISCUSSION AND CONCLUSIONS}

This was a retrospective study using bra size, height and weight, self-reported both pre- and postoperatively by patients who underwent reduction mammoplasty by a single surgeon over a two-year period. With $69(75.8 \%)$ respondents, the response rate was considered high.

The average BMI was $29.6 \mathrm{~kg} / \mathrm{m}^{2}$. The Centers for Disease Control and Prevention, Atlanta, Georgia considers anyone with a BMI of $25 \mathrm{~kg} / \mathrm{m}^{2}$ to $29.9 \mathrm{~kg} / \mathrm{m}^{2}$ to be overweight and those with a BMI $30 \mathrm{~kg} / \mathrm{m}^{2}$ or greater to be obese (5). Thus, almost one-half of the patients studied would be considered obese. The mean BMI showed little change after surgery, indicating any changes to the bra cup size were directly due to reduction mammoplasty rather than weight loss.

The present study introduces a new way of standardizing bra cup sizes. Conversion of a conventional bra size, with both its band and cup sizes, to a standardized bra cup size is useful, giving us a value that can be compared arithmetically and identifying breasts of similar volume, regardless of bra size. Thus, the 
standardized cup size enables us to compare the volume of breast tissue across different band and bra cup sizes.

A weakness of our study is that it used self-reported data, particularly, bra size pre- and postoperatively. The literature suggests that the frequency of inaccurate bra size or improperly fitting bras in patients seeking reduction mammoplasty is $70 \%$ to $100 \%(2,3)$. In Greenbaum et al's study (3), the true band size was on average four inches larger than the reported size. The current study design does not allow us to determine the proportion of patients in the wrong bra size, but it is likely that it is at least $25 \%$. Specifically, for the group that reported no change in bra cup size after the removal of a mean of $577 \mathrm{~g}$ of tissue from each breast; it is extremely unlikely that a woman wearing a properly fitting bra would have no change in bra size given this amount of tissue removed. Of note, this group of patients, with a mean BMI of $30.3 \mathrm{~kg} / \mathrm{m}^{2}$, was more obese when compared with the average BMI of $29.6 \mathrm{~kg} / \mathrm{m}^{2}$. Additionally, it is interesting that this group of patients was generally satisfied with their postoperative results, suggesting that their original poorly fitting bra fitted them better after surgery. It is quite likely that even more patients were originally in improperly fitting bras; however, it is impossible to confirm this supposition from the current information.

Greenbaum et al (3) alludes to the reasons why patients may be in improperly fitted bras and the difficulty in determining the correct bra size according to the shape of the breast. In general, it is difficult to obtain bras in the larger sizes, and even if they are found, they tend to be in a more utilitarian style. Thus, a large-breasted woman who wants to wear an attractive bra is often forced to buy a smaller size. Additionally, at department stores, larger size bras are generally more expensive than regular size bras and many women are unwilling or unable to purchase their best suited undergarment. Women may also buy a poorly fitting bra out of ignorance because it can be quite difficult to determine the correct bra size needed and, if the selection is not available, the woman may not appreciate the difference between an appropriate and poorly fitting bra.

Given the likelihood that $25 \%$ to $100 \%$ of our patients were in the wrong bra size preoperatively, it would be invalid to use the data to draw conclusions about the expected change in cup size according to the amount of tissue removed.

\section{Why is it important for plastic surgeons to understand bra sizing?}

Some surgeons suggest that, given the inaccuracy in bra sizing, commercial bra sizing should not be considered as a criterion in assessing patients requesting surgery. However, standard bra sizing provides a common system for conveying the patient's concerns and expectations pre- and postoperatively. The plastic surgeon is often required to translate the standards of the fashion industry into outcomes for the patient.

Although it can be difficult to accurately determine the patient's correct bra size, it is a useful technique for the plastic surgeon to check the band size because this will give an approximate and immediate estimate of whether the patient is in the correct size, even if it is not possible to determine the exact cup size. For instance, if the patient is wearing a $38 \mathrm{E}$ bra, but has a chest circumference of 40 inches, indicating a true band size of 44, the cup size should be downsized accordingly and the patient may actually require a $44 \mathrm{~B}$ cup. The plastic surgeon may question whether a patient who is already a B cup truly requires surgery to alleviate symptoms. Also, the patient, once informed of their true size, may opt out of reduction mammoplasty because she would not want to go below a B cup. Thus, checking the band size can be a reality check for both the plastic surgeon and the patient alike.

A future study will prospectively measure patients to determine accurate pre- and postoperative bra sizes to assess whether the mass of tissue removed can be correlated to the change in cup size. A study is also planned to assess whether patients wearing an appropriately fitted bra experience an alleviation of symptoms and, therefore, choose not to undergo surgery. Furthermore, these studies will assess whether patients with improved knowledge of their true bra size will decide against surgery because they are already a B or C bra cup size.

ACKNOWLEDGEMENTS: The authors of this paper wish to thank Julia Quick RN for her diligent data collection; Isabel Lavrador for her excellent clerical skills; Robin S Roberts M Tech for his advice on statistical analysis.

\section{REFERENCES}

1. Tezel E, Numanoglu A. Practical do-it-yourself device for accurate volume measurement of breast. Plast Reconstr Surg 2000;105:1019-23.

2. Pechter EA. A new method for determining bra size and predicting postaugmentation breast size. Plast Reconstr Surg 1998;102:1259-65.

3. Greenbaum AR, Heslop T, Morris J, Dunn KW. An investigation of the suitability of bra fit in women referred for reduction mammoplasty. Br J Plast Surg 2003;56:230-6.

4. Bra making class notes by Beverly Johnson.

<http://www.bramakers.com/bms_classnotes.html> (Version current at February 18, 2005).

5. BMI - Body mass index: BMI for adults: What does this all mean? $<$ http://www.cdc.gov/nccdphp/dnpa/bmi/bmi-means.htm> (Version current at June 18, 2004). 